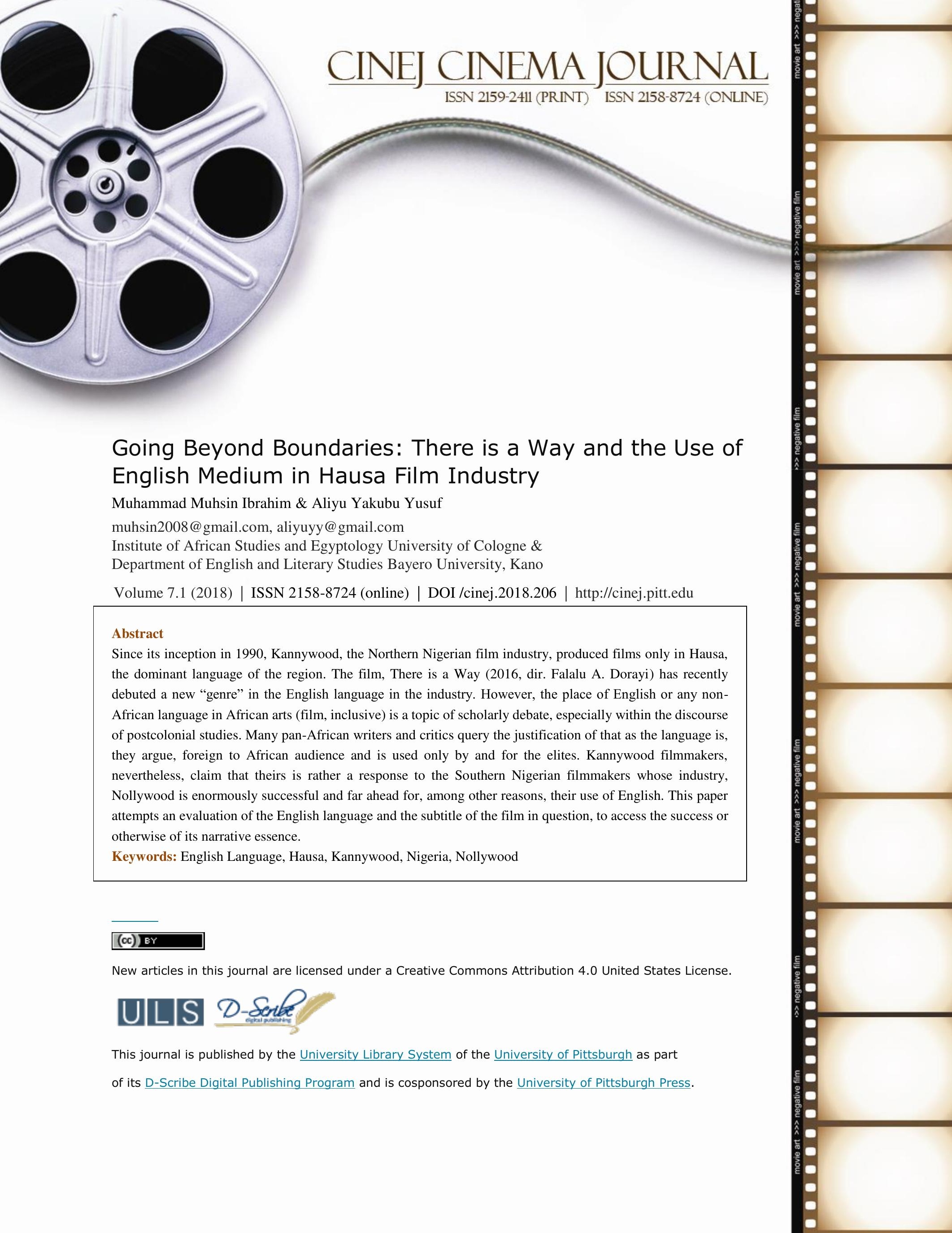




\section{Going Beyond Boundaries: There is a Way and Use of English Medium in Hausa Film Industry}

\section{Muhammad Muhsin Ibrahim \& Aliyu Yakubu Yusuf}

\section{Introduction}

The name, Nollywood appeared for the first time in a New York Times article titled "Step aside, Los Angeles and Bombay, for Nollywood" by Norimitsu Onishi in September 2002 (see: Jedlowski, 2011; McCain, 2013; Adamu, 2014). The naming came a decade after Kenneth Nnebue's Living in Bondage, which is always credited as the first Nollywood film. McCain (2013) notes that the term has been contested by those who resent the cultural imperialism that is evident in naming a Nigerian product after Hollywood. Idegu (2014:176) objects it strongly and describes it as a reflection of "alien cultural behaviour". Haynes (2007:2), however, argues that though the name is problematic, it is

"here to stay because the term is irresistible to journalists and, more importantly, because it neatly expresses powerful aspirations by people in the video film industry and by their fans to have a big, glamorous entertainment industry that can take its place on the world scene and appeal to international audiences."

Today, the name is not only accepted, but also the film industry was declared the world second biggest in terms of production after Bollywood (UNESCO Institute for Statistics 2009). Its films are now "the most watched and the most available in African households" (Tcheuyap 2011) in Ugor (2016:18). Above all, according to some contestable statistics, "The movie industry in Nigeria [Nollywood] is currently the largest employer after agriculture" (Itah 2014). Whether this is factual or not, nobody doubts the accomplishment of Nollywood in terms of popularity within and beyond African continent if nothing else.

On its part, Kannywood was born in 1990 with the first Hausa language film, Tirmin Danya in Kano. Historically, therefore, the Hausa video film industry was established at least two years 
earlier than the southern Nigerian film industry (Adamu 2012:248). However, today Nollywood is seen as "the default" Nigerian films (Adesokan 2011:99), because of their use of English, among other reasons. Jedlowski (2011:16) further notes that "[the] English-language films were the ones that travelled the furthest and were most popular abroad". In her assessment, McCain (2013:30) points out that "In most scholarly discussions of Nollywood, Hausa films are footnoted as an “other" to Nollywood...", notwithstanding its being older than the latter.

To, perhaps, bridge this widening gap between the two industries, a few Kannywood filmmakers subtitle their films. Moreover, another trigger for the subtitle as Lere (2014) discovered, was "the introduction of the African Magic Hausa channel on DSTV...to accommodate a wider non-Hausa speaking viewership across the continent”. The subtitles are, mostly, however, incorrect with broken tenses and phrases. In many instances, the grammar is very poor, the spellings error-ridden, and this, ultimately, destroys the objective of the subtitles and creates a false idea of the movie to the non-Hausa speaker. The language used can best be described as "Engausa", a hybridised English and Hausa languages, not anything close to the Standard English.

These reasons motivated the executive producer of There is a Way to sponsor the making of the first Kannywood film in 'Standard' English, according to an interview with him on Arewa24 television channel (see: “Kundin Kannywood”, Episode 93; YouTube). He further noted that he made efforts to reach to the film industry stakeholders to correct things. As they did not, he felt the need to delve into filmmaking, to bring the desired change by himself.

The challenges facing Kannywood are manifold, the English subtitle imbroglio is only a minuscule. The industry suffers more snobbery especially from the hegemonic Muslim scholars, though argument between religion and the art is as old as the art itself. The one between Islam and film is equally very old and marked by a much more suspicion than it has ever been the case with 
other religions. This is due to Islam's stiff stand against many things readily obtainable in films such as role-play, male-female interaction and the manner of dressing, particularly of the women acting unruly female cast, among other things. While the rejection and dejection of the arts continue, the peoples' craving for entertainment grows.

Kannywood functions amidst the hurricane described above. The filmmakers try hard and harder to set up a niche within this Islamicate environment. The English genre is yet another decisive effort to uplift the image of the embattled film industry, as the executive producer of the film under study told us during a personal interview in Kano, Nigeria. ("Kabiru Musa Jammaje” interview by the author on 12/02/2018).

\section{The Film, There is a Way}

There's a Way does not only present the lower and upper classes struggle; the predatory nature of some university dons is equally bared. As a token, the women issue is not left untouched. Thus it is used to set the story afloat. The film opens with a court scene where a woman, abused by her husband, is questioned by the judge. The husband allegedly forces her to abort pregnancies six times. Isham (Nuhu Abdullahi), as a secondary student, witnesses the hearing and becomes interested in studying Law to assist the poor such as the wife who is evidently harmed. His dream is, however, not meant to materialise quickly and easily.

After failing his exams at least twice, Isham, the curious boy from a low-income family does not have money to register at a "miracle centre", where candidates register for exams and "nobody ever fails". He someday accompanies his friend to the centre and mistakenly bumps into Fadila (Hajara Jalingo), whose father gives her a hundred thousand naira (N100, 000) to register at the centre. The 'accident' is love at first sight. Days, perhaps months, pass, and then destiny 
brings them together as students at the same university. While her father every so often warns her against mingling with anyone from an underprivileged family, Isham and his two siblings are orphans raised by their sick mother.

As expected, Fadila's father, Alhaji Mahdi (Sani Mu'azu) someday finds out that she has invited Isham to the house, though with the consent of her mother. He blasts them and chases Isham out. He asks his old friend, Dr Bello (Umar Malumfashi), a lecturer at Isham’s university, to find ways to victimise him. Coincidently, Dr Bello is already at loggerhead with Isham over a protest the latter organises against the sale of a handout. Unknown to Mahdi, however, is that his friend has once tried to sleep with his daughter. Finally, Isham is framed and subsequently expelled. He is soon consoled and offered sponsorship by Fadila to study in any southern Nigerian university willing to accept him.

Mahdi tries to marry Fadila off to her cousin whom he fosters at his house and sends abroad for studies. She rebuffs. Isham returns, and his relationship with Fadila soon gets rejuvenated. The lady Dr Bello used in framing Isham asks him for her payment. He refuses, and thus she threatens to expose him. And, in the final scene, the Economic and Financial Crime Commission (EFCC) arrests Mahdi for an undisclosed crime.

\section{There is a Way as an Experimentation}

Historically, There is a Way is not the first film in English in Kannywood. Wasila (dir. Ishaq Sidi Ishaq) was shot first in Hausa in 2000. Following its resounding success, the filmmakers decided to reshoot it in English for a wider audience. They did but, from our inquiries, the film flopped, putting an end to doing any more film in the English language in the struggling film industry. The reemergence of this practice is, arguably, a second attempt to bring back the English language as a medium for the film in the industry. It is noteworthy that the producers of There is 
$a$ Way have made two more films in the language, one of which is its sequel. However, as it is with many experimentations, there are noticeable bloopers in the narrative voices of the story as will be pointed out and analysed in the following parts of this paper.

Perhaps due to the fear of the inadequacy or unsuitability of the voices of some of the actors in the film, the executive director who, from the auteurist point of view, is the engine power behind the film, uses his voice for at least three characters in different scenes. The voice is strikingly identical. The implication of this in this paper is much; the curious audience may inquire whether or not the casts can truly speak English or they only struggle while others that failed had to have their voices replaced by another's. There are also a few, possible typographical errors or grammatical mistakes in the subtitle.

The diction in particular romantic scenes is quite unsuitable for communicative usage as it is too flowery. These include the lines spoken when Fadila and Isham first meet. Although it meant to express love, the language is too pretentious and barely used for verbal communication. Moreover, most of the casts try their best possible in internalising their lines. It is only, as per our evaluation, the character of El-Mustapha who speaks quite unnaturally. However, the Arewa 24 channel reviewers criticised the actors' overall internalisation of their lines and characterised it as poor and as one of the film's biggest mistakes.

\section{The Data}

The data presented in the table below constitutes 33 sentences that are extracted from the film. As far as the rules of the Standard English is concerned, the sentences found to manifest some usage errors. While some of the errors are discovered in the subtitle of the film, few others are the 
result of (mis)pronunciation of the characters in the film. Side-by-side with each sentence is its possible correct version.

\begin{tabular}{|c|c|c|}
\hline S/No. & Sentences Extracted from the Film & Possible Correct Version of the Sentences \\
\hline 1. & Will you told the court your name? & Will you tell the court your name? \\
\hline 2. & $\begin{array}{l}\text { It seems you have been married for a } \\
\text { while without a childs. }\end{array}$ & $\begin{array}{l}\text { It seems you had been married for a while } \\
\text { without a child. }\end{array}$ \\
\hline 3. & $\begin{array}{l}\text { I have been pregnant six times in the six } \\
\text { years that we have spent together. }\end{array}$ & $\begin{array}{l}\text { I had been pregnant six times in the six years we } \\
\text { [had] spent together. }\end{array}$ \\
\hline 4. & $\begin{array}{l}\text { Fadila, I have never thought we would } \\
\text { ever meet again. Why would you think } \\
\text { so? }\end{array}$ & $\begin{array}{l}\text { Fadila, I have never thought we would ever meet } \\
\text { again. Why did you think so? }\end{array}$ \\
\hline 5. & I am so sorry, Isham. I don't know. & I am so sorry, Isham. I didn’t know. \\
\hline 6. & $\begin{array}{l}\text { I want you to know that my parents did } \\
\text { not send me to this school to misbehave. }\end{array}$ & $\begin{array}{l}\text { I want you to know that my parents do not send } \\
\text { me to this school to misbehave. }\end{array}$ \\
\hline 7. & You didn't ask how I knew your name. & You didn't ask how I know your name. \\
\hline 8. & I didn't bring in the paper. & I do not bring in the paper. \\
\hline 9. & I am glad I came to you. & I am glad I have come to you. \\
\hline 10. & $\begin{array}{l}\text { Why did it take you so long before having } \\
\text { a childs? }\end{array}$ & $\begin{array}{l}\text { Why did it take you so long before having a } \\
\text { child? }\end{array}$ \\
\hline 11. & $\begin{array}{l}\text { Probably that was why he repeatedly } \\
\text { force me to abort our babies. }\end{array}$ & $\begin{array}{l}\text { Probably that was why he repeatedly forced me } \\
\text { to abort my previous pregnancies. }\end{array}$ \\
\hline 12. & $\begin{array}{l}\text { Your ex-husband claim that Kamal is not } \\
\text { his son. }\end{array}$ & $\begin{array}{l}\text { Your ex-husband claims that Kamal is not his } \\
\text { son. }\end{array}$ \\
\hline 13. & $\begin{array}{l}\text {...the man Sunusi allege of fathering } \\
\text { Kamal. }\end{array}$ & ...the man Sunusi alleges of fathering Kamal. \\
\hline 14. & Is it a dream or reality? & Is it a dream or a reality? \\
\hline 15. & $\begin{array}{l}\text { Isham, when life throws you a lemon, } \\
\text { make lemonade. }\end{array}$ & $\begin{array}{l}\text { Isham, when life throws you a lemon, make a } \\
\text { lemonade. }\end{array}$ \\
\hline 16. & We will work a solution together. & We will work on a solution together. \\
\hline 17. & $\begin{array}{l}\text { Now I will call on Dr. Bello, a } \\
\text { seniorlecturer in this faculty, to deliver } \\
\text { his speech. }\end{array}$ & $\begin{array}{l}\text { Now I will call on Dr Bello, a Senior Lecturer in } \\
\text { this Faculty, to deliver his speech. }\end{array}$ \\
\hline
\end{tabular}




\begin{tabular}{|c|c|c|}
\hline 18. & $\begin{array}{l}\text { In our faculty, we seriously punish } \\
\text { anyone who disobeys school rules and } \\
\text { regulations. }\end{array}$ & $\begin{array}{l}\text { In our Faculty, we seriously punish anyone who } \\
\text { disobeys school rules and regulations. }\end{array}$ \\
\hline 19. & $\begin{array}{l}\text { Now I am going to call on the faculty } \\
\text { exam officer to come and make his } \\
\text { remarks. }\end{array}$ & $\begin{array}{l}\text { Now I am going to call on the Faculty Exams } \\
\text { Officer to come and make his remarks. }\end{array}$ \\
\hline 20. & $\begin{array}{l}\text { I also want to make you a managing } \\
\text { director of a new company. }\end{array}$ & $\begin{array}{l}\text { I also want to make you the Managing Director } \\
\text { of a new company. }\end{array}$ \\
\hline 21. & $\begin{array}{l}\text { I want you to find his faculty and } \\
\text { department. }\end{array}$ & $\begin{array}{l}\text { I want you to find about his Faculty and } \\
\text { Department. }\end{array}$ \\
\hline 22. & I appreciate. & I appreciate it. \\
\hline 23. & I really appreciate. & I really appreciate it. \\
\hline 24. & OK, we may live to see the day. & OK, may we live to see the day. \\
\hline \multicolumn{3}{|l|}{25.} \\
\hline 26. & I learn that still you are a small girl. & I learn that you are still a small girl. \\
\hline 27. & If you don't mind, can I offer you a lift? & If you don't mind, can I give you a lift? \\
\hline 28. & ...so that you will separate them for ever. & $\begin{array}{l}\text {...so that you will break up their relationship } \\
\text { forever. }\end{array}$ \\
\hline 29. & $\begin{array}{l}\text { And I'm assure you will be the first } \\
\text { student to enter the exam hall. }\end{array}$ & $\begin{array}{l}\text { And I'm sure you will be the first student to enter } \\
\text { the exam hall. }\end{array}$ \\
\hline 30. & Let's go and do the work together. & Let's go and do some work together. \\
\hline 31. & ...it's time for prayer. & ...it's time for prayers. \\
\hline 32. & $\begin{array}{l}\text { In school, you learn from lectures, from } \\
\text { the books, from your classmates and, of } \\
\text { course, from the physical environment of } \\
\text { the school. }\end{array}$ & $\begin{array}{l}\text { In school, you learn from lectures, from books, } \\
\text { from your classmates and, of course, from the } \\
\text { physical environment of the school. }\end{array}$ \\
\hline 33. & $\begin{array}{l}\text { To keep the soul alive and healthy, one } \\
\text { must learn continuously all through his } \\
\text { life. }\end{array}$ & $\begin{array}{l}\text { To keep the soul alive and healthy, one must } \\
\text { learn continuously all through their life. }\end{array}$ \\
\hline
\end{tabular}

\section{Data Analysis}


From the table above, it is evident that most of the identified sentences exhibit evidence of wrong tense usage. It is important to note that for someone to fully identify some of the sentences as wrong, one needs to watch the film and find out the circumstances in which they are used. In other words, a cursory look at the sentences will suggest that nothing is wrong with most of the selected sentences. But if one critically examines the context they appear in; one can see why we classified them as grammatically incorrect. Below is their grammatical analysis.

1. Will you told the court your name?

This sentence shows an incorrect mixture of two different tenses. Huddleston (1988:80) argues that the use of will often expresses future actions. Again, Choy and Clark (2006:34) note that will is a helping verb which always comes before the main verb and that if a question contains a helping verb, the helping verb still comes before the main verb. This is what happens with the sentence above. What is wrong with the sentence is the fact that the main verb which follows will appears is a participle verb (Participles are verbs in their various progressive, past and past participle forms) and not an infinitive (Infinitives are verbs in their base forms and can be preceded by to). Supporting this claim, Quirk \& Greenbaum (1973:47) remark that when will appears sideby-side with the main verb, the main verb must be in infinitive form. That is, about the identified sentence, the verb told - a participle — should be tell — an infinitive. Hence the expression * Will you told the court your name should be rendered as Will you tell the court your name?

2. It seems you have been married for a while without a childs.

3. Why did it take you so long before having a childs?

The judge in the first scene of the film uttered these sentences. One of the problems with them is the wrong pluralisation of the noun child. Kirkpatrick (2013:84) argues that some irregular nouns like $o x$ and child form their plurals by adding - en. In this way, the plural forms of $o x$ and child become oxen and children respectively. This means the word child never takes the addition 
of $s$ as the above sentences erroneously suggest. Another problem with the sentences is the discordance between the article $a$ and the supposed noun ${ }^{*}$ childs. One of the uses of the indefinite article $a$ as identified by Murthy (2007:52), is that it is used in the sense of one. Therefore, you cannot have $a$ followed by a plural form of the noun, as seemingly used in the two sentences. Thus, the sentences can be corrected in two ways: It seems you have been married for a while without a child/It seems you have been married for a while without children and Why did it take you so long before having a child?/Why did it take you so long before having children?

4. I have been pregnant six times in the six years that we have spent together.

This sentence was uttered in the courtroom to a judge by a woman called Umma Aimana whose ex-husband, Sanusi, claims that her son Kamal is not his son. She was telling the court that before her conception of Kamal, she had six pregnancies aborted by Sanusi. The sentence I have been pregnant six times in the six years that we have spent together is in present perfect tense, which according to Leech \& Svartvik (2002:69) means "past-happening-related-to-present-time”. Murthy (2007:155) also argues that the present perfect tense is used to show that an action has just been completed. And looking at the fact that Umma Aimana was expressing an action which happened some years ago when she was together with Sanusi as his wife, the use of the present perfect tense in the sentence is incorrect. In other words, since Umma Aimana's expression was meant to depict an action which happened and ended in the past, the use of the simple past tense or the past perfect tense is more appropriate. Therefore, the sentence can be modified as I had been pregnant six times in the six years we had spent together, or I was pregnant six times in the six years we spent together.

5. Isham: Fadila, I have never thought we would ever meet again.

1. Fadila: Why would you think so? 
This is a dialogue that took place between two of the central characters, Isham and Fadila. Considering that Isham was telling Fadila he had never thought they would meet again at the time when they had already met again, then the response given by Fadila (Why would you think so) is unusual. That is since Isham's thoughts are in the past, Fadila's response should also be in the same tense: Why did you think so?

6. I am so sorry, Isham. I don't know.

This is used by Fadila to apologise to Isham for not knowing about his mother's illness. But by saying I don't know, it suggests that Fadila was not aware of the illness at the time she apologised to Isham — which was not the case. According to Quirk and Greenbaum (1973:35) did is one of the forms of the primary auxiliary verb do and is used to talk about past actions. And since Fadila intended to say that she was not aware of Isham's mother's sickness before he told her at the time they met, the correct tense she should have employed is the past simple: I am so sorry. I didn't know (about the illness).

7. I want you to know that my parents did not send me to this school to misbehave.

8. I didn't bring in the paper.

As explained previously (see Quirk \& Greenbaum, 1973; Leech \& Svartvik, 2002; Huddleston, 1988; Kirkpatrick, 2014), one of the relationships between do and did is that while the former is used for present actions, the latter is used to express past actions. Fadila uttered the first sentence here as a warning to Dr Bello who tried to seduce her, while the second was said to an invigilator by A'isha Abdul, a student who was caught with a paper containing answers in the exam hall. In both circumstances, the characters were trying to explain a present situation. And by using didn't instead of $d o n$ 't, it appears as if they are explaining something that happened in the past. However, since what the characters tried to explain was happening at the moment they talk 
about it, the sentences can be modified this way: I want you to know that my parents do not send me to this school to misbehave and I don't bring in the paper.

9. You didn’t ask how I knew your name.

This sentence is used by A'isha Abdul when she met Isham at the entrance to the exam hall. The incorrectness of the sentence arises because of the use of the past form of the verb knew instead of the present form know. This is because by using knew, it suggests that A'isha has no longer known Isham's name anymore. In other words, her knowledge of his name was in the pastwhich is not the case.

10. I am glad I came to you.

This sentence is used by Mahdi to express his happiness to have gone to Dr Bello about his willingness to see Isham punished for associating with Fadila. This sentence also shows the incorrect application of the past tense. As explained by Murthy (2007:157) the simple past tense is used to show an action that started and finished in the past. And looking at the fact that Mahdi was together with Dr Bello at the time he expressed his happiness, then the correct tense to have been used is present perfect-I am glad I have come to you. This is so because the present perfect tense is used "[...] to refer an action in the past which has a result continuing to the present (Kirkpatrick 2014:174)

11. Probably that was why he repeatedly force me to abort our babies.

12. Your ex-husband claim that Kamal is not his son.

13. ...the man Sunusi allege of fathering Kamal.

These three sentences manifest a clear violation of the basic rule of concord (i.e. the agreement between the subject and the verb). For example, sentence 11 was used by Umma Aimana in reference to how her Ex-husband made her abort her six pregnancies. And since the 
issue happened some years back, all the verbs in the sentence should be in the past tense, which Kirkpatrick (2014:172) describes as the one used to refer to an event or state that occurred at some point in the past. By saying $[\ldots]$ he repeatedly force me $[\ldots]$, there is no agreement between the subject he and the verb force. The past form of the verb (forced) should, therefore, be used, as in Probably that was why he repeatedly forced me to abort our babies.

As for sentences 12 and 13, the information conveyed is in the simple present tense, which is used to describe an action that takes place at present (Murthy, p. 151). Kirkpatrick (2014:168) adds that the simple present tense "uses the base form, also known as the infinitive form of the verb, as walk, run, make, go but it changes in the third person singular when it adds $-s$ to the base form, sometimes with a spelling changes, as walks, runs, makes, goes". Again, Choy and Clark (2006:47) hold that any verb ending in $-s$ is singular. Considering this fact, there is no agreement between the subjects and the verbs in sentences 12 and 13. In other words, because the subject is in the third person singular in both cases, the verbs should take the addition of $-s$, as in Your exhusband claims that Kamal is not his son and ...the man Sunusi alleges of fathering Kamal.

14. Is it a dream or reality?

15. Isham, when life throws you a lemon, make lemonade.

The problem with these sentences is that they do not follow the rule of parallel structure. Parallel structure is the term used to explain that in writing, similar ideas should be expressed in similar grammatical structure. That is, when you write two or more pieces of information or any list, the items should be put in a similar form (see Wilson \& Glazier, 2009; Choy \& Clark, 2006). For example, I like to hike to ski and going sailing (Not parallel). I like to hike, to ski and to sail (Parallel). Looking at these examples, one can argue that sentences 14 and 15 are somewhat not parallel. This is because the two-information conveyed in the sentences-though in the same grammatical forms_-(nouns), are slightly not parallel. The first items (a dream/a lemon) contain 
an article and a noun, while the second items (reality/lemonade) contain nouns only. Because of this inconsistency, the sentences can be modified as Is it a dream or a reality and Isham, when life throws you a lemon, make a lemonade. By doing this, the sentences appear more parallel than they were.

16. Now I will call on Dr. Bello, a seniorlecturer in this faculty, to deliver his speech.

17. In our faculty, we seriously punish anyone who disobeys school rules and regulations.

18. Now I am going to call on the faculty exam officer to come and make his remarks.

19. I also want to make you a managing director of a new company.

20. I want you to find his faculty and department.

The five sentences identified above exhibit failure to use capital letters in some names and titles. Ahmad et al. (1999:50) and Murthy (2007:323) argue that among the areas that require capitalisation include historical events, laws, organisations, offices, departments and titles of people and names of things when we refer to unique examples. For this reason, names and titles such as Senior Lecturer, the Faculty, the Department, the Exams Officer and Managing Director should all begin with a capital letter - a rule which is violated in the sentences above.

\section{I appreciate.}

\section{I really appreciate.}

The two sentences above used the transitive verb "appreciate" as if it were an intransitive verb. As defined by Kirkpatrick (2014:187), transitive verbs are verbs which can take a direct object, while intransitive verbs do not take a direct object. According to Online Oxford Learners Dictionary (2018), the verb appreciate is used as a transitive verb in all its senses except one; and that is when it is used to refer to increase in value over a period, as in Their investments have appreciated over the years. In this example, the verb is used in its intransitive form. But looking 
at the above instances in which the verb is used in the film, it is evident that it is used in the sense of being grateful for something that someone has done. In this case, the verb is used as a transitive verb and should, therefore, be followed by an object, such as I appreciate your assistance or I really appreciate it and so on.

23. OK, we may live to see the day.

24. Can you imagine that she took a stupid boy to my house called Isham?

25. I learn that still you are a small girl.

The problem with these sentences is the improper arrangement of the words in the way that will help convey the intended message to the audience. Sentence 24 , for example, was uttered to Isham by his friend Aminu, when the discussion about Fadila came up. The sentence is used as an expression of prayer; therefore, it should be rendered to sound as such-OK, may we live to see the day. Sentence 25 was uttered by Mahdi when he was recounting how Fadila invited Isham to his house. The sentence is riddled with structural ambiguity that makes it difficult for someone to understand whether Isham is the name of the invited boy or that of the house. Thus, to disambiguate, the sentence should be restructured to read Can you imagine that she took a stupid boy called Isham to my house? Finally, the use of the word still in sentence 26 is also somewhat incorrect. Therefore, it can be rearranged as I learn that you are still a small girl.

26. If you don't mind, can I offer you a lift?

27. ... so that you will separate them for ever.

28. And I'm assure you will be the first student to enter the exam hall.

The three sentences here suffer from the wrong choice of vocabulary. According to Merriam Webster Dictionary (2018), the word lift which appears in sentence 27 can be used as either a verb or a noun. As a noun, one of its senses means "a ride in a vehicle", as in She gave me a lift to school. In Standard English, therefore, lift is given and not offered, as used in sentence 27. 
Thus, the sentence can be modified as If you don't mind, can I give you a lift? Similarly, the bone of contention in sentence 27 is the use of the word separate. When the word is used in the sense of parting away of a man and a woman in a relationship, it means to temporarily cease to live together, probably because of an existing tension but with the hope of reuniting in future. In sentence 28 however, the word is not used as such. And since Mahdi intends to bring an end to the relationship between his daughter Fadila and Isham, he should not have used the word separatewhich has a different connotation in Standard English. Instead, the sentence should be [...] so that you will break them up forever. Again, sentence 29 also shows a failure to use the right vocabulary. By saying And I'm assure you will be the first student to enter the exam hall, the word assure is used as it were an adjective rather than a verb. To correct this error, its adjective form assured or sure can be used instead: And I'm assured/sure you will be the first student to enter the exam hall.

29. We will work a solution together.

This sentence shows the omission of the preposition on that is useful in conveying the intended information. According to Merriam Webster Dictionary (2018), one of the words with which work collocates is the preposition on, as in "work on", which means to shape, form or improve something. As used in the sentence extracted from the film, the word work is employed to talk about finding out or forming a solution to the problems that bedevilled the relationship between Isham and Fadila. As such, work on would have better fit the context than work, as in We will work on a solution together.

30. Let's go and do the work together.

31. In school, you learn from lectures, from the books, from your classmates and, of course, from the physical environment of the school. 
In these two sentences, there is a wrong usage of the definite article the. According to Leech and Svartvik (2002:150), "the definite article is used to express definiteness in all kinds of nouns (except proper nouns, such as Susan, Asia or San Francisco, which do not take an article)". Murthy (2007:51-52) adds that the definite article is used to refer to a particular person or things and also for persons or things mentioned for the second time. In the two sentences above, these rules are violated.

Isham's mother uttered sentence 31 to his sister who had just returned from school. Prior to her return, the mother had just finished talking to Isham about some work she wanted to do. Therefore, the sister did not know about the existence of the work. Neither did she know what kind of work it was. This makes the use of the definite article the as the modifier to the noun work wrong. Instead, the sentence should have read Let's go and do some work together.

As for sentence 32, it was used during students' orientation (though, not explicitly stated in the film) to encourage students to learn from all things in their surroundings. In the sentence, the use of the definite article the to modify the noun book is incorrect. This is because the speaker was talking about books in general, not some specific books. And because books were mentioned for the first time in the scene, therefore, it is wrong to use the before books. In other words, the noun book should contain zero article, as in In school, you learn from lectures, from books, from your classmates and, of course, from the physical environment of the school.

32. ...it's time for prayer.

According to Merriam Webster Dictionary (2018), the word prayer is often used in plural (prayers) when referring to a religious service offered to God or the gods. And since in the film, the word is used in this sense, it should have been pluralised. That is, [...] it is time for prayers.

33. To keep the soul alive and healthy, one must learn continuously all through his life. 
One of the features of traditional grammar is its propensity to discriminate against women in language use. That is to say, in situations where the gender of the person being talked about is not known, it was common to use male nouns or pronouns. For example, any student who fails this exam should have HIMSELF to blame. "Himself" here is a male pronoun, and it is obvious that there could be female students who might also fail the exam. This is what is referred to as sexism in language use. This is what is found in sentence 34. To avoid sexism in grammar, Kirkpatrick (2013:39) suggests that the word his can be replaced by its plural their. And although this usage appears ungrammatical, it was accepted and used widely in reference books and school textbooks. Therefore, the sentence can be rendered To keep the soul alive and healthy, one must learn continuously all through their life.

\section{Conclusion}

Film industries around the world have made films in their local languages and yet get large following beyond their borders. Typical examples today are the Indian and Korean films. The popularity of the former requires no mention while that of the latter is still emerging and getting huge momentum since the turn of the millennium. The secret does not squarely lie in their medium, but in the artistry with which they produce their films. An audience must not understand the diction spoken by actors to identify with their characters, laugh at their antics and cry at their misfortune, as the case may be. Often, however, they use an impeccable subtitle. Kannywood filmmakers should borrow a leaf out of their Indian and Korean counterparts' book.

In spite of its few failings, There is a Way is a remarkable, bold experiment. Nevertheless, it remains a challenge for Kannywood filmmakers to know that for their products to gain more attention, acceptance and recognition, they need more innovation and conscientious effort, not only using the global language of English. 


\section{BIBLIOGRAPHY}

Adamu, A. U. (2007). 'Currying favour: eastern media influences and the Hausa video film' in the Journal of Film International; vol. 5, no. 4: p. 77-89; 2007

(2012). "The Emergence and Characteristics of Kannywood as a Hausa Video Film Industry in Northern Nigeria" in Daraja, Y. B. et al. (Eds.) (2012). Perspectives on the Study of Contemporary Kano. Zaria: Ahmadu Bello University Press.

(2013). "Transgressing Boundaries: Reinterpretation of Nollywood Films in Muslim Northern Nigeria" in Krings, M. and Okome, O. (Eds.) Global Nollywood: The Transnational Dimension of an African Video Film Industry. Indianapolis: Indiana University Press.

Adesokan, A. (2011). “Anticipating Nollywood: Lagos circa 1996.” Social Dynamics. 37.1: 96110.

Ahmad, S. B. et al. (1999). Essential English for school certificate. Ibadan: Spectrum Books Limited.

Arewa24, "Kundin Kannywood, Episode 93". Retrieved from:

https://www.youtube.com/watch?v=XQBU0zRZsik on 07/03/2018

Choy, P. \& Clark, D. G. (2006). Basic grammar and usage. Boston: Wadsworth Cengage Learning.

Idegu, E. U. (2014). "Which change, what change? Glamorising social misfits in selected Nigerian home movie." In International Journal of English and Literature. Vol. 5(8), pp. 174181; DOI: 10.5897/IJEL2014.0621

Itah, Joe. "NEPC, ZAFAA to create an export path for Nollywood." Nigerian Export Promotion Council (NEPC). 25 Mar. 2014. Web. 14 Apr. 2014.

Jedlowski, A. (2011). "Videos in Motion: Processes of Transnationalization in the Southern Nigerian Video Industry: Networks, Discourses, Aesthetics.” Diss. The University of Naples, 'L'Orientale,'

Haynes, J. (2007). "Nollywood: What's in a Name” in Film International. 5.4; 106-108.

Huddleston, R. (1988). English grammar: An outline. Cambridge: CUP. 
Kirkpatrick, B. (2013). Better English usage. Glasgow: Geddes \& Grosset.

Kirkpatrick, B. (2014). Better English grammar. Glasgow: Geddes \& Grosset.

Leech, G. \& Svartvik, J. (2002). A communicative grammar of English. Delhi: Dorling Kindersley.

Lere, M. (2014). Shoddy English Subtitles in Hausa Films Results in 'Engausa'. Retrieved from: https://www.premiumtimesng.com/entertainment/167858-shoddy-english-subtitles-of-hausafilms-results-in-engausa.html on 07/03/2018

McCain, C. (2013). "Nollywood and Its Others: Questioning English Language Hegemony in Nollywood Studies." The Global South. 7.1: 30-54.

Murthy, J. D. (2007). Contemporary English grammar. Lagos: Book Master

Quirk, R. \& Greenbaum, S. (1973). A university grammar of English. Edinburgh: Pearson

Education Limited.

Tcheuyap, A. (2011). Postnationalist African Cinemas. Manchester: Manchester University Press.

Ugor, P. (2016). Nollywood: Popular Culture and Narratives of Youth Struggles in Nigeria. Durham: Carolina Academic Press.

Wilson, P. \& Glazier, T. F. (2009). The least you should know about English writing skills. Boston: Wadsworth Cengage Learning.

\section{FILMOGRAPHY}

Falalu A. Dorayi. 2016. There is a Way 